\section{Factors Related with Frontal Dysfunction in Early Stages of Parkinson Disease}

\section{Julio López Argüelles ${ }^{1 *}$, Aleima B Rodríguez Carvajal², Georgina González Alba', Leydi M Sosa Aguila ${ }^{3}$ and Lisan Montalvo Manso ${ }^{1}$}

${ }^{1}$ Departament of Neurology, University Hospital Gustavo Aldereguía Lima, Cuba

${ }^{2}$ Departament of Neuropsychology, University Hospital Gustavo Aldereguía Lima, Cuba

${ }^{3}$ Genetic Center, University Hospital Paquito González Cueto, Cienfuegos, Cuba

\begin{abstract}
Introduction: Parkinson Disease (PD) although described initially by James Parkinson as a disease with motor disorder it has been demonstrated that the cognitive disorders in the form of disejecutive syndrome are frequent worsening with the evolution.

Objective: To characterize the Frontal Dysfunction (FD) in the patients with $\mathrm{PD}$ and to determine the factors related with frontal dysfunction in early stages.

Method: We studied 125 patients with diagnosis of idiopathic PD and Hoehn and Yahr Stages <2, to those which it was carried to them out survey with demographic, clinical and neuropsychological data studies included the Frontal Assessment Battery (FAB).

Results: The mean age was of $68.1 \pm 8.6$, the onset age was of $62.6 \pm 10.5$, the diestrums predominated and those which initiated with tremor. Of the 125 patients $71.4 \%$ presented FD, with an average of the $F A B$ of $11.82 \pm 3.7$. The age $(R=-0.45 ; p<0.001)$ and onset age $(R=-0.33 ; p=0.02)$ showed inversely proportional correlation
\end{abstract}

*Corresponding author: Julio López Argüelles, 67 street, \% 56 y 58, Edif A Apto 1, Cienfuegos, Cuba, Tel: +53 54218333; E-mail: juliola@jagua.cfg.sld.cu; julito.arguelles@gmail.com

Citation: Argüelles JL, Carvajal ABR, Alba GG, Aguila LMS, Manso LM (2019) Factors Related with Frontal Dysfunction in Early Stages of Parkinson Disease. J Alzheimers Neurodegener Dis 5: 018.

Received: December 13, 2018; Accepted: January 17, 2019; Published: January 31,2019

Copyright: (C) 2019 Argüelles JL, et al. This is an open-access article distributed under the terms of the Creative Commons Attribution License, which permits unrestricted use, distribution, and reproduction in any medium, provided the original author and source are credited. with the FD. Other related variables were the schooling up to second level $(p=0.003)$ and the rural origin with significance $<0.001$.

Conclusion: The age and onset age higher than 60 years, the lower schooling than second level of teaching, rural origin and the presence of cognitive dysfunction are related to FD in early stages of PD.

Keywords: Dementia; Frontal assessment battery; Frontal dysfunction; Mini mental state examination; Montreal test; Parkinson disease

\section{Introduction}

Parkinson Disease (PD) was described for first time in 1817 by James Parkinson in their monograph of 66 pages An Essay on the shaking palsy [1]. PD kept as the second degenerative disorder of the central nervous system after Alzheimer disease [2-4]. Although was initially described as a disease with motor disorder has been demonstrated that the cognitive disorders in the form of disejecutive syndrome are frequent in PD worsening with the evolution [5-13]. The patients have difficulty in maintaining adaptive responses with visuospatials and visuoperceptuals deficits, who leads to alteration of the memory of work and attentional deficits [14]. Has been demonstrated that the signs of frontal disease are well represented in subcortical pattern dementias, whose prototype can be PD [15-20]. With the present article we intended to characterize the frontal dysfunction in patients with PD and to determine the factors related with frontal dysfunction in early stages of PD.

\section{Methods}

A cross-sectional study, descriptive was conducted, to the patients with PD who went to the consultation of this disease of the University Hospital Dr. Gustavo Aldereguía Lima. With in a period of a year for the same include all the patients in early stage of Parkinson disease (Hohen and Yahr Stages $\leq 2$ ), in total 125 patients who fulfilled the following criteria: Patients with diagnosis of PD in stages I and II of Hohen and Yahr, excluding: Atypical parkinsonism or secondary, patients with severe depression or delirum, patients with cognitive deterioration such that does not make it possible to conduct the neuropsychological study [21].

\section{Procedure the study was carried out in two phases}

First phase (phase of collection of clinical data): In this phase an interview structured with clinical, sociodemographic data and risk factors for frontal dysfunction, where it will be included age, sex, race and other demographic data as well as it will be carried out the scale UPDRS motor and scale of Hoehn and Yahr in order to determine the stage of its disease.

Second phase (phase of neuropsychological study): In this phase worked with the 125 patients, sample obtained then to be classified the patients according to the Stages of Hoehn and Yahr to those which were carried them out several neuropsychological tests: The Mini Mental State Test (MMSE), Montreal Cognitive Assessment (MoCA), depression scale of Hamilton or Ysavage for patients older than 60 years. For the assessment of the frontal dysfunction was in addition used the Frontal Assessment Battery (FAB). 
Citation: Argüelles JL, Carvajal ABR, Alba GG, Aguila LMS, Manso LM (2019) Factors Related with Frontal Dysfunction in Early Stages of Parkinson Disease. J Alzheimers Neurodegener Dis 5: 018.

\section{Frontal Assessment Battery (FAB)}

As Dubois et al. indicate, it consists of an exploration of the characteristic functions of the frontal lobes through six subtest: Similarities (formation of concepts), verbal fluidity (mental flexibility), motor series (programming), interference (realization of conflicting instructions), control (inhibition of responses), and autonomy (independence of the exterior environment) [22]. Each subtest is assessed from 0 to 3 points and, as a result, the maximum scoring is of 18 points. For the classification of the frontal dysfunction we take: As frontal dysfunction the scoring was lower than 15 points. The cut off point for the frontosubcortical deficit we locate it in 16-15, and the cut off point for dementia frontosubcortical, in 14-12 [23].

\section{Cognitive deterioration}

Finally the diagnosis of each patient was carried out according to the criteria for Diagnostic and Statistical Manual of Mental Disorders (DMS-IV). The severity of the deterioration will be evaluated through the criteria for Parkinson Dementia (PD), taking as mild cognitive deterioration to the patients who presented scorings of the MMSE and MoCA between 23 and 26 points the patients who presented scorings lower than the previous ones were considered carrier of dementia [13].

\section{Statistical analysis}

For processing of the data the SPSS v15.0 statistical program for windows was utilized. There was considered statistically significant one $p<0.05$. There were compared the values of the averages of the demographic variables (age, onset age, time of evolution, schooling) and clinical (UPDRS scale, predominant symptom, clinical onset) related to the frontal dysfunction of the patients through the Student's t. A correlation of the values of the FAB was in addition carried out with the clinical and demographic variables through Pearson's correlation coefficient, increasing its significance when the values of $\mathrm{R}$ come closer to one.

Consequently, during the planning of this research we will respect the ethical principles of research on human beings $[12,13]$.

\section{Results}

In table 1 we found the onset age $62.6 \pm 10.5$ years old and the current age $68.1 \pm 8.6$ years old, remain as well as the world average in the sixth decade of life, prevailing the form of beginning tremoric, in addition the time of evolution mean was of $5.6 \pm 4.3$ years in spite of being in the first motor stages of the DP, with a mean of the motor UPDRS in On and Off that does not arrive at the 20 points.

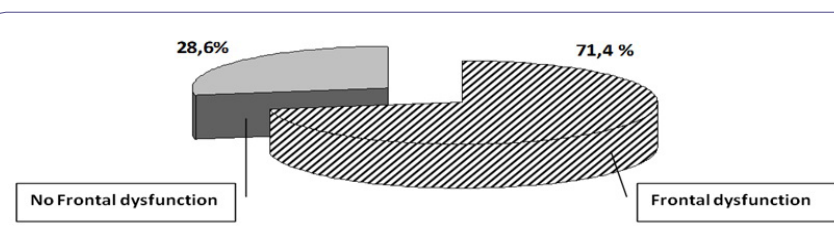

Graph 1: Distribution of the patients according to the frontal activity.

With regard to the variables related to the frontal dysfunction (Table 2) we found that the patients who presented frontal dysfunction had an average of age higher than those which remained with the adequate frontal functions ( $\mathrm{p}=0.02$ ), occurring the same with the variables that measure global cognitive alteration basically the MoCA where its values differ between groups presenting a mean of $16.9 \pm 4.3$ $(p<0.0001)$.The MMSE also showed a relevant difference between groups with an statistical significance $(\mathrm{p}=0.01)$.

\begin{tabular}{|c|c|}
\hline Variables & Mean \pm SD \\
\hline Age & $68.1 \pm 8.6$ \\
\hline Onset age & $62.6 \pm 10.5$ \\
\hline Time of evolution (years) & $5.6 \pm 4.3$ \\
\hline UPDRS motor On & $14.7 \pm 6.0$ \\
\hline UPDRS motor Off & $18.6 \pm 6.4$ \\
\hline Clinical Variables of the Sample Given in Percentage \\
\hline Variables & Percentage \\
\hline Clinical onset tremoric/Rigid-acinetic & $77.6 / 27.7$ \\
\hline Diestrums/Left-handed & $81.6 / 2.6$ \\
\hline Predominant symptom tremor/Rigidity & $53.7 / 46.3$ \\
\hline \multicolumn{2}{|c|}{ Source: Conducted survey } \\
\hline & Table 1: Relation of the clinical variables of the sample. \\
\hline
\end{tabular}

\begin{tabular}{|c|c|c|c|}
\hline & Frontal Dysfunction & $\begin{array}{c}\text { Without Frontal } \\
\text { Dysfunction }\end{array}$ & $\mathbf{p}$ \\
\hline Age & $69.91 \pm 7.89$ & $64.39 \pm 9.8$ & 0.02 \\
\hline UPDRS motor On & $14.74 \pm 5.9$ & $14.38 \pm 5.35$ & 0.82 \\
\hline UPDRS motor Off & $18.41 \pm 6.23$ & $18.50 \pm 5.9$ & 0.96 \\
\hline MoCA & $16.9 \pm 4.3$ & $21.56 \pm 2.77$ & $<0.0001$ \\
\hline MMSE & $22.17 \pm 3.4$ & $24.13 \pm 2.09$ & 0.01 \\
\hline Source: Conducted survey & \\
\hline
\end{tabular}

Table 2: Relationship between the mean $\pm \mathrm{SD}$ of clinical/demographic variables and the presence of frontal dysfunction.

In table 3 we found that the average of the $\mathrm{FAB}$ was lower in the patients with rural origin $(\mathrm{p}<0.001)$, those which attended only up to the second level of teaching $(10.9 \pm 3.9 ; \mathrm{p}=0.003)$, onset age and current age older than 60 years with a significance of 0.02 and 0.025 respectively. Not occurring statistical significance among the stages I and II of Hoehn and Yahr although showed mean of the FAB lower in the stage I.

\begin{tabular}{|c|c|c|c|}
\hline \multicolumn{2}{|c|}{ Variables } & \multirow{2}{*}{$\begin{array}{r}\text { Mean } \pm \text { SD } \\
14.30 \pm 2.7\end{array}$} & $\mathbf{p}$ \\
\hline \multirow{2}{*}{ Age } & $\leq 60$ años & & \multirow{2}{*}{0.025} \\
\hline & $>60$ años & $11.43 \pm 3.8$ & \\
\hline \multirow{2}{*}{ Onset age } & $\leq 60$ años & $13.22 \pm 2.8$ & \multirow{2}{*}{0.02} \\
\hline & $>60$ años & $10.78 \pm 3.9$ & \\
\hline \multirow{2}{*}{ Origin } & Rural & $10.13 \pm 3.6$ & \multirow{2}{*}{$<0.001$} \\
\hline & Urban & $14.22 \pm 2.9$ & \\
\hline \multirow{2}{*}{ Schooling } & Up to second level & $10.9 \pm 3.9$ & \multirow{2}{*}{0.003} \\
\hline & After the second level & $13.95 \pm 2.7$ & \\
\hline \multirow{2}{*}{$\begin{array}{c}\text { Stage of Hoehn and } \\
\text { Yahr }\end{array}$} & STAGE I & $11.11 \pm 2.6$ & \multirow{2}{*}{0.43} \\
\hline & STAGE II & $12.21 \pm 3.9$ & \\
\hline
\end{tabular}

Table 3: Relation of the mean $\pm \mathrm{SD}$ of the FAB and clinical/demographic variables according to $t$ student. 
Upon establishing the correlation among the clinical and demographic variables with the values of the FAB (Table 4) we find that the age $(R=-0.45 ; p<0.001)$ and onset age $(R=-0.33 ; p=0.002)$ showed an inversely proportional correlation in relation with regard to the values of the FAB. The schooling showed gave directly proportional values $(\mathrm{R}=0.43 ; \mathrm{p}=0.001)$, that is to lower values of the schooling lower values of the FAB. The rest of the clinical variables did not show statistical significance including the evolution time.

\begin{tabular}{|c|c|c|}
\hline $\mathbf{m = 1 1 . 8 2} \pm \mathbf{3 . 7}(\mathbf{a})$ & $\mathbf{R}$ & $\mathbf{p}$ \\
\hline Age & $-0.45^{* *}$ & $<0.001$ \\
\hline Onset age & -0.33 & 0.02 \\
\hline Schooling & 0.43 & 0.001 \\
\hline UPDRS motor On & -0.08 & 0.6 \\
\hline UPDRS motor Off & -0.1 & 0.9 \\
\hline Time of evolution (years) & 0.14 & 0.3 \\
\hline
\end{tabular}

Table 4: Correlation of demographic and motor variables with the FAB's scoring.

** The correlation is significant at level 0.01 (bilateral).

(a) Mean of the $\mathrm{FAB} \pm$ Standard deviation.

In the graph 2 can see as the means items of the FAB, in all study's pacients, that presented lower values were the fluidity and motor series, occurring the opposite with the behavior of compenzación with an almost equal average value to 3.00 , that is maximum value.

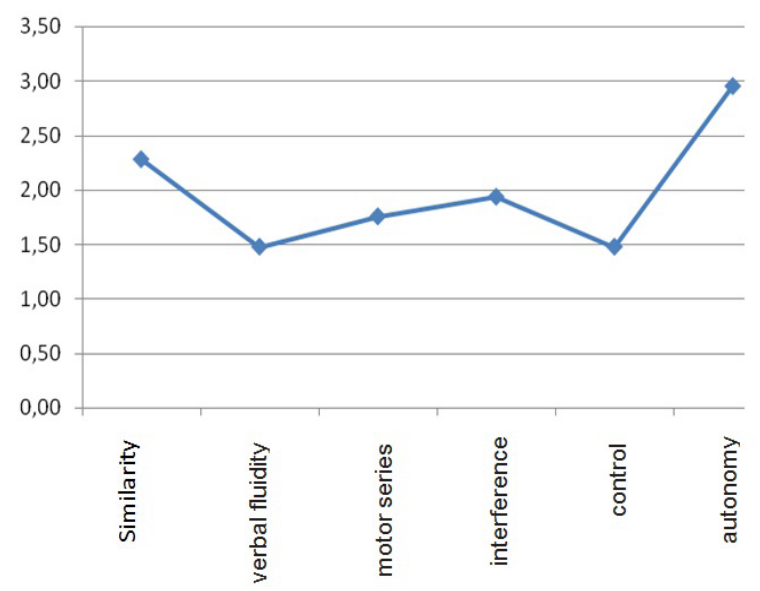

Graph 2: More affected frontal functions in early stage of Parkinson's disease (according to FAB).

\section{Discussion}

The present study emphasizes us that the frontal affectations are presented at onset of the PD.

Analyzing the demographic variables these do not differ from the reviewed studies that have dealt with widely this subject, being noteworthy that the majority of the patients present a schooling that does not surpass the secondary teaching bearing no relation this with the origin that presents both similar percentages for those which are of rural origin and urban [24].

The age is kept as one of the principal variables related to the frontal dysfunction, being able to be in relation this with which as advances the age occur cognitive alterations, although the average for this of our study was of 68.1 years, being noteworthy that the motor scales of the PD did not show a statistically significant relation, occurring the opposite with the neuropsychological scales that demonstrate the presence of global cognitive alteration, represented by the association of frontal dysfunction with the MoCA and MMSE what translates that in the beginning of the EP not only are affected prefrontal cortical areas, but also parietal areas and rising subcorticales systems, that they utilize other neurotransmitters; in addition to parts of the striate one as putamen, caudate or nucleus accumbens that is associated with the implicit learning of habits or of incentive response and sensoriomotor coordination, most adequate planifcación of each incentive $[25,26]$.

Furthermore find that both the age and the onset age present an inversely proportional correlation, which is to greater age and greater onset age smaller scoring of the FAB and greater frontal dysfunction, with a greater significance for a point of cut off greater than 60 year $[27,28]$.

With the results of this study is shown that the affectation in the frontal lobes comes together with the onset of the disease, then seem to be affected different cortico-subcortical circuits that act parallels and similar with regard to their structure and organization, affecting in this form the closed circuit that is originated in a private area of the frontal cortex that transmits the information through the basal nodes and returns to the place of departure in the lobe frontal.

Furthermore occurs specific disorder: In the motor circuits that leads to the classical acinesia or bradycinesia, the dorsolateral frontal circuit that is translated into a disejecutive syndrome with disability for the mental flexibility and the change of criteria, in planning and generation of strategy, in the organization of the actions, in the utilization of the experience and in the production of a spontaneous activity, in addition to the previous cingular circuit by the presence of the reduction of the initiative and the maintenance of the attention.

\section{Conclusion}

The present study demonstrates that already in early stages of PD occurs degeneration in different frontal cortical regions as the motor cortex, premotor, dorsolateral and cingular area. With variables that are related to the frontal dysfunction as the age and onset age above 60 years, the lower schooling than second level of teaching as well as the presence of generalized cognitive affectation.

\section{Acknowledgement}

None.

\section{Conflict of Interest}

The author declares there is no conflict of interest.

\section{References}

1. Parkinson J (1817) An Essay on the Shaking Palsy Londr, Sherwood, Neely and Jones. 
Citation: Argüelles JL, Carvajal ABR, Alba GG, Aguila LMS, Manso LM (2019) Factors Related with Frontal Dysfunction in Early Stages of Parkinson Disease. J Alzheimers Neurodegener Dis 5: 018.

2. López-Argüelles J, Carbajal AB, García S, Sosa LM, et al. (2014) Cognitive deterioration in initial stage of Parkinson Disease. Rev Neuropsic neuropsiq neurociencias 14: 77-79.

3. Kitayama M, Wada-Isoe K, Nakaso K, Irizawa Y, Nakashima K (2007) Clinical evaluation of Parkinson's disease dementia: association with aging and visual hallucination. Acta Neurol Scand 116: 190-195.

4. Ransmayr G (2007) Clinical criteria of Parkinson's disease. Ther Umsch 64: $5-8$.

5. Kandiah N, Narasimhalu K, Lau PN, Seah SH, Au WL, et al. (2009) Cognitive decline in early Parkinson's disease. Mov Disord 24: 605-608.

6. Muslimović D, Post B, Speelman JD, De Haan RJ, Schmand B (2009) Cognitive decline in Parkinson's disease: a prospective longitudinal study. J Int Neuropsychol Soc 15: 426-437.

7. D'Amelio M, Ragonese P, Morgante L, Reggio A, Callari G, et al. (2006) Long-term survival of Parkinson's disease: a population-based study. J Neurol 253: 33-37.

8. Cooper JA, Sagar HJ, Jordan N, Harvey NS, Sullivan EV (1991) Cognitive impairment in early, untreated Parkinson's disease and its relationship to motor disability. Brain 114: 2095-2122.

9. Capriotti T, Terzakis K (2006) Parkinson Disease. Home Healthc Now 34: 300-307

10. Oliveira GN, Souza CP, Foss MP, Tumas V, (2015) An analysis of the cognitive items of the movement disorders society checklist for the diagnosis of dementia in patients with Parkinson's disease. Parkinsonism Relat Disord 21: 1260-1263.

11. Vera-Cuesta H, Vera-Acosta H, Varez-Gonzalez L, Fernandez-Maderos I, Casabona-Fernandez E (2006) Disfunción frontal en la enfermedad de Parkinson idiopática. Rev Neurol 42: 76-84.

12. Manzini JL (2000) Declaración de Helsinki: Principios éticos para la investigación médica sobre sujetos humanos. Acta bioeth 6: 321-334.

13. Asociacin Americana de Psiquitría. Manual diagnóstico y estadístico de los trastornos mentales. Barcelona: Masson; 2002.

14. Toribio-Diaz ME, Carod-Artal FJ (2015) Subtipos de deterioro cognitivo leve en la enfermedad de Parkinson y factores predictores de conversión a demencia. Rev Neurol 61: 14-24.

15. Lannuzel A, Hoglinger GU, Verhaeghe S, Gire L, Belson S, et al. (2007) Atypical parkinsonism in Guadeloupe: a common risk factor for two closely related phenotypes? Brain 130: 816-827.

16. Moorhouse P, Gorman M, Rockwood K (2009) Comparison of EXIT-25 and the Frontal Assessment Battery for evaluation of executive dysfunction in patients attending a memory clinic. Dement Geriatr Cogn Disord 27: $424-428$
17. Nagata T, Ishii K, Ito T, Aoki K, Ehara Y, et al. (2009) Correlation between a reduction in Frontal Assessment Battery scores and delusional thoughts in patients with Alzheimer's disease. Psychiatry Clin Neurosci 63: $449-454$

18. Thabit H, Kennelly SM, Bhagarva A, Ogunlewe M, McCormack PM, et al. (2009) Utilization of Frontal Assessment Battery and Executive Interview 25 in assessing for dysexecutive syndrome and its association with diabetes self-care in elderly patients with type 2 diabetes mellitus. Diabetes Res Clin Pract 86: 208-212.

19. Lima CF, Meireles LP, Fonseca R, Castro SL, Garrett C (2004) The Frontal Assessment Battery (FAB) in Parkinson's disease and correlations with formal measures of executive functioning. J Neurol 255: 1756-1761.

20. Jódar-Vicente M (2004) Funciones cognitivas del lóbulo frontal. Rev Neurol 39: 179-182.

21. Hughes AJ, Daniel SE, Kilford L, Lees AJ (1992) Accuracy of clinical diagnosis of idiopathic Parkinsin's disease: A clinico-pathological study of 100 cases. J Neurol Neurosurg Psychiatry 55: 181-184.

22. Dubois B, Slachevsky A, Litvan I, Pillon B (2000) The FAB: a frontal assessment battery at bedside. Neurology 55: 1621-1626.

23. Rodriguez del AA, Catalan Alonso MJ, Carrasco ML (2003) [FAB: a preliminar Spanish application of the frontal assessment battery to 11 groups of patients]. Rev Neurol 36: 605-608.

24. Kummer A, Harsányi E, Dias FM, Cardoso F, Caramelli P, et al. (2009) Depression impairs executive functioning in Parkinson disease patients with low educational level. Cogn Behav Neurol 22: 167-172.

25. Braak H, Rüb U, Jansen Steur EN, Del TK, de Vos RA (2005) Cognitive status correlates with neuropathologic stage in Parkinson disease. Neurology 64: 1404-1410.

26. Peng D, Shi Z, Xu J, Shen L, Xiao S, et al. (2016) Demographic and clinical characteristics related to cognitive decline in Alzheimer disease in China: A multicenter survey from 2011 to 2014. Medicine (Baltimore) 95: 3727.

27. Zhang S, Ou R, Chen X, Yang J, Zhao B, et al. Correlative factors of cognitive dysfunction in PD patients: a cross-sectional study from Southwest China. Neurol Res 38: 434-440.

28. Bocanegra Y, Trujillo-Orrego N, Pineda D (2014) Dementia and mild cognitive impairment in Parkinson's disease: A review. Rev Neurol 59: 555-569. 


\section{di}

Journal of Anesthesia \& Clinical Care

Journal of Addiction \& Addictive Disorders

Advances in Microbiology Research

Advances in Industrial Biotechnology

Journal of Agronomy \& Agricultural Science

Journal of AIDS Clinical Research \& STDs

Journal of Alcoholism, Drug Abuse \& Substance Dependence

Journal of Allergy Disorders \& Therapy

Journal of Alternative, Complementary \& Integrative Medicine

Journal of Alzheimer's \& Neurodegenerative Diseases

Journal of Angiology \& Vascular Surgery

Journal of Animal Research \& Veterinary Science

Archives of Zoological Studies

Archives of Urology

Journal of Atmospheric \& Earth-Sciences

Journal of Aquaculture \& Fisheries

Journal of Biotech Research \& Biochemistry

Journal of Brain \& Neuroscience Research

Journal of Cancer Biology \& Treatment

Journal of Cardiology: Study \& Research

Journal of Cell Biology \& Cell Metabolism

Journal of Clinical Dermatology \& Therapy

Journal of Clinical Immunology \& Immunotherapy

Journal of Clinical Studies \& Medical Case Reports

Journal of Community Medicine \& Public Health Care

Current Trends: Medical \& Biological Engineering

Journal of Cytology \& Tissue Biology

Journal of Dentistry: Oral Health \& Cosmesis

Journal of Diabetes \& Metabolic Disorders

Journal of Dairy Research \& Technology

Journal of Emergency Medicine Trauma \& Surgical Care

Journal of Environmental Science: Current Research

Journal of Food Science \& Nutrition

Journal of Forensic, Legal \& Investigative Sciences

Journal of Gastroenterology \& Hepatology Research

Journal of Gerontology \& Geriatric Medicine
Journal of Genetics \& Genomic Sciences

Journal of Hematology, Blood Transfusion \& Disorders

Journal of Human Endocrinology

Journal of Hospice \& Palliative Medical Care

Journal of Internal Medicine \& Primary Healthcare

Journal of Infectious \& Non Infectious Diseases

Journal of Light \& Laser: Current Trends

Journal of Modern Chemical Sciences

Journal of Medicine: Study \& Research

Journal of Nanotechnology: Nanomedicine \& Nanobiotechnology

Journal of Neonatology \& Clinical Pediatrics

Journal of Nephrology \& Renal Therapy

Journal of Non Invasive Vascular Investigation

Journal of Nuclear Medicine, Radiology \& Radiation Therapy

Journal of Obesity \& Weight Loss

Journal of Orthopedic Research \& Physiotherapy

Journal of Otolaryngology, Head \& Neck Surgery

Journal of Protein Research \& Bioinformatics

Journal of Pathology Clinical \& Medical Research

Journal of Pharmacology, Pharmaceutics \& Pharmacovigilance

Journal of Physical Medicine, Rehabilitation \& Disabilities

Journal of Plant Science: Current Research

Journal of Psychiatry, Depression \& Anxiety

Journal of Pulmonary Medicine \& Respiratory Research

Journal of Practical \& Professional Nursing

Journal of Reproductive Medicine, Gynaecology \& Obstetrics

Journal of Stem Cells Research, Development \& Therapy

Journal of Surgery: Current Trends \& Innovations

Journal of Toxicology: Current Research

Journal of Translational Science and Research

Trends in Anatomy \& Physiology

Journal of Vaccines Research \& Vaccination

Journal of Virology \& Antivirals

Archives of Surgery and Surgical Education

Sports Medicine and Injury Care Journal

International Journal of Case Reports and Therapeutic Studies

Submit Your Manuscript: http://www.heraldopenaccess.us/Online-Submission.php 